\title{
Sour times: seawater acidification effects on growth, feeding behaviour and acid-base status of Asterias rubens and Carcinus maenas
}

\author{
Yasmin S. Appelhans*, Jörn Thomsen, Christian Pansch, Frank Melzner, \\ Martin Wahl
}

Marine Ecology, Helmholtz Centre for Ocean Research (GEOMAR), Düsternbrooker Weg 20, Kiel 24105, Germany

\begin{abstract}
The impact of seawater acidification on calcifying organisms varies at the species level. If the impact differs between predator and prey in strength and/or sign, trophic interactions may be altered. In the present study, we investigated the impact of 3 different seawater $\mathrm{pCO}_{2}$ levels $(650,1250$ and $3500 \mu \mathrm{atm})$ on the acid-base status or the growth of 2 predatory species, the common sea star Asterias rubens and the shore crab Carcinus maenas, and tested whether the quantity or size of prey consumed is affected. We exposed both the predators and their prey, the blue mussel Mytilus edulis, over a time span of $10 \mathrm{wk}$ and subsequently performed feeding experiments. Intermediate acidification levels had no significant effect on growth or consumption in either predator species. The highest acidification level reduced feeding and growth rates in sea stars by $56 \%$, while in crabs a $41 \%$ decrease in consumption rates of mussels could be demonstrated over the $10 \mathrm{wk}$ experimental period but not in the subsequent shorter feeding assays. Because only a few crabs moulted in the experiment, acidification effects on crab growth could not be investigated. Active extracellular $\mathrm{pH}$ compensation by means of bicarbonate accumulation was observed in C. maenas, whereas the coelomic fluid $\mathrm{pH}$ in A. rubens remained uncompensated. Acidification did not provoke a measurable shift in prey size preferred by either predator. Mussels exposed to elevated $\mathrm{pCO}_{2}$ were preferred by previously untreated A. rubens but not by C. maenas. The observed effects on species interactions were weak even at the high acidification levels expected in the future in marginal marine habitats such as the Baltic Sea. Our results indicate that when stress effects are similar (and weak) on interacting species, biotic interactions may remain unaffected.
\end{abstract}

KEY WORDS: Acidification $\cdot \mathrm{pH} \cdot \mathrm{CO}_{2} \cdot$ Interactions $\cdot$ Predation $\cdot$ Sea star $\cdot \mathrm{Crab} \cdot$ Mussel

\section{INTRODUCTION}

The brackish western Baltic Sea is a relatively species-poor environment. Two of the main benthic predators in the western Baltic are the common sea star Asterias rubens and the shore crab Carcinus maenas. A large proportion of their prey consists of the highly abundant blue mussel Mytilus edulis. Regionally, the bivalve can cover 95 to $100 \%$ of all suitable substrate, especially if predators are absent (e.g. Kautsky \& van der Maarel 1990, Reusch \& Chapman 1997). Adult crabs and sea stars, however, consume mussels only to the threshold size of $\sim 48 \mathrm{~mm}$ shell length, beyond which size refuge is obtained (Sommer et al. 1999, Enderlein et al. 2003, Laudien \& Wahl 2004). The protective effect could be due to large size, strong adductor muscles and/or more robust shells. Any factor prolonging the time that a mussel spends in sub-threshold size properties diminishes its chances for survival. Reduced growth 
can lead to shifts in trophic interactions with increasing overall predation impact on the mussel population (e.g. Enderlein \& Wahl 2004). In addition, when changing environmental conditions affect the feeding rates and/or prey size range of sea stars and crabs, shifts in trophic interactions with communitywide consequences may be expected.

The predicted ocean acidification (IPCC 2007) is one of the environmental shifts with this potential. Seawater acidification at a global and long-term scale is caused by the anthropogenic increase of atmospheric $\mathrm{CO}_{2}$, which, at smaller spatial and temporal scales, may be overridden by biological and biogeochemical processes (Thomsen et al. 2010). Until the end of the century, oceanic pH decreases of 0.3 to 0.4 units (equivalent to atmospheric $\mathrm{CO}_{2}$ levels of 650 uatm and above) can be expected (Feely et al. 2004, Caldeira \& Wickett 2005). Due to the unique structure of the Baltic Sea with its generally low salinity but strong stratification and pronounced oxygen minimum zones occurring in the summer below the pycnocline, $\mathrm{pCO}_{2}$ levels here can be naturally high, especially in benthic regions. The surface water $\mathrm{pCO}_{2}$ in this region occasionally exceeds values of $2300 \mu \mathrm{atm}$ and is thus higher than expected for the open ocean within the next $300 \mathrm{yr}$ (Thomsen et al. 2010). Recent model calculations indicate that with increasing atmospheric $\mathrm{CO}_{2}$ levels, Baltic surface $\mathrm{pCO}_{2}$ will rise overproportionally. Thus, with a doubling of atmospheric concentrations from currently 385 to future $761 \mu$ atm, surface water $\mathrm{pCO}_{2}$ is expected to seasonally reach peak values of $>4000 \mu \mathrm{atm}$ in the study area (Thomsen et al. 2010). Moreover, the $\mathrm{pH}$ in this region is expected to fluctuate more than under open ocean conditions because $\mathrm{CO}_{2}$ effects are not buffered as strongly, mainly due to the lower concentration of $\mathrm{HCO}_{3}{ }^{-}$and thus lower total alkalinity $\left(A_{T}\right)$ (Beldowski et al. 2010). These properties (low salinity and thus low $A_{T}$ ) are found in many estuarine and coastal systems. Research to date has focused mainly on pelagic open ocean conditions and may be of little relevance to benthic organisms (cf. Beldowski et al. 2010).

It has traditionally been assumed that seawater acidification will most severely affect calcifying organisms (e.g. Fabry 2008). In fact, several recent studies have shown that acidified conditions may affect (in one direction or other) early development (Kurihara et al. 2004, 2007, Kurihara \& Shirayama 2004, Dupont et al. 2008, Ellis et al. 2009), growth and calcification (Michaelidis et al. 2005, Gazeau et al. 2007, Kurihara et al. 2008, Wood et al. 2008, Gooding et al. 2009, Thomsen et al. 2010) and diverse physiological traits (Michaelidis et al. 2005, Metzger et al. 2007, Miles et al. 2007, Thomsen et al. 2010, Thomsen \& Melzner 2010) of calcifying echinoderms, crustaceans and bivalves.

The strength of acidification impacts on calcifiers varies at the species level (Hall-Spencer et al. 2008, Melzner et al. 2009, Gutowska et al. 2010, Hendriks et al. 2010, Kroeker et al. 2010, Whiteley 2011). This variation is due in part to variable combinations of calcite, aragonite and organic matrix in the respective skeletons. While the exoskeleton of crustaceans consists solely of relatively stable calcite, the shell of mussels, such as Mytilus edulis, is composed partly of calcite and partly of the more soluble aragonite. The skeleton of echinoderms consists of Mg-calcite, a form of carbonate even more soluble than aragonite (Andersson et al. 2008). Moreover, as suggested by Melzner et al. (2009), highly active organisms, such as crabs, due to their high ion-regulatory and extracellular fluid buffering capacity, may be less sensitive to seawater acidification than less active groups (e.g. sea stars and mussels). Also, species from groups that compensate their extracellular fluid $\mathrm{pH}$ by active accumulation of $\mathrm{HCO}_{3}{ }^{-}$, such as cephalopods (Gutowska et al. 2008) or teleost fish (Checkley et al. 2009), hypercalcify when being chronically exposed to acidified seawater. This response is thought to be mostly due to the excess amount of accumulated $\mathrm{HCO}_{3}{ }^{-}$, which could lead to an increase in calcification via a change in ionic driving forces across calcifying epithelia (Gutowska et al. 2010). Finally, the amount of organic material covering the outer skeleton layer may influence the sensitivity towards acidification in the different groups (e.g. Tunnicliffe et al. 2009)

The feeding modes of the 2 predator species differ. Carcinus maenas crushes the shells to consume the flesh, whereas Asterias rubens slowly pulls the shells apart and digests the soft body in its everted stomach. With increasing shell size, mussel consumption is reduced, by crabs due to handleability and a larger stability of the molluscan shell, by starfish by an increased strength of the muscle adductor muscle, i.e. the amount of myofibrils in smooth muscles and energy available to prolong the catch phase (e.g. Twarog 1967), during which mussels keep their shells closed with minimal energy investment. The different modes of feeding of the 2 predator species may be differently affected by acidification. A study of the brittlestar Amphiura filiformis by Wood et al. (2008) proposed that not only carbonate structures but also the quantity of muscle tissue might be influenced by acidification. If the amount of smooth mus- 
cle fibres in the adductor muscles of bivalves is reduced, or if for any reason the catch mechanism is disturbed, sea star feeding should be facilitatedunless their muscles, too, are weakened. If the calcification of mussel shells is reduced and shells become less stable, crabs may be able to consume a larger quantity and larger sizes of mussels per unit time, again unless they themselves are negatively affected by acidification.

The aim of the present study was to test whether seawater acidification affects the susceptibility of Mytilus edulis to predation by Asterias rubens and Carcinus maenas, the main controlling factors of this mussel species in the western Baltic. We attempted to differentiate between the influence of acidification on predators and on prey. We hypothesised that (1) if interacting species are differently affected by acidification, their trophic interaction should shift, and (2) acidification on the consumer side should affect sea stars (noncompensating) more than crabs (compensating). To date, very few studies have focused on the predator-prey interaction between organisms under acidified conditions (Bibby et al. 2007, Gooding et al. 2009), although such indirect effects of stress may be substantially stronger than their direct impact (Wahl 2008).

\section{MATERIALS AND METHODS}

\section{Sampling}

All of the organisms investigated were sampled in the Kiel Fjord (western Baltic Sea) via dredging or manual collection in April 2009. The size spectra of selected test animals at the start of the experiment were as follows: Asterias rubens $15.5 \pm 3.5 \mathrm{~g}$ wet wt and $4.5 \pm$ $0.5 \mathrm{~cm}$ arm length; Carcinus maenas $4.5 \pm 0.5 \mathrm{~cm}$ carapace width; Mytilus edulis ( 3 classes) $2.00 \pm 0.15 \mathrm{~cm}$, $3.00 \pm 0.15 \mathrm{~cm}$ and $4.00 \pm 0.15 \mathrm{~cm}$ shell length (SL).

\section{Experimental design}

The experimental units (EUs) consisted of 21 plastic aquaria connected to a flow-through system of seawater from Kiel Fjord. The water was pre-treated in 3 interconnected header-tanks via bubbling with pressurized air into which different concentrations of $\mathrm{CO}_{2}$ (ambient conditions, $1120 \mu \mathrm{atm}$ and $4000 \mu \mathrm{atm}$ ) were mixed. Water from the header-tanks then streamed into the EUs at a flow rate of 5 to $6 \mathrm{l} \mathrm{h}^{-1}$ and was additionally bubbled with the above-mentioned $\mathrm{CO}_{2}$ and air mixtures. In this way, we established 3 different treatment levels (Table 1). Due to the naturally acidified conditions of water in the Kiel Fjord (see above), the lowest treatment levels (with a mean of $650 \mu \mathrm{atm}$, see Table 1) were substantially higher than the currently $\sim 380 \mu$ atm $\mathrm{CO}_{2}$ prevailing in the atmosphere.

To each single EU, we added either one crab, one sea star or 20 mussels of all 3 size classes (60 mussels in total per EU). The 3 treatment levels were replicated 10 times for each prey or consumer species, resulting in a setup of $90 \mathrm{EUs}$. In each EU containing mussels, 3 random mussels of each size class were individually marked to allow for growth monitoring. Asterias rubens were fed ad libitum with mussels of $3.50 \pm 0.35 \mathrm{~cm} \mathrm{SL}$, and Carcinus maenas were fed ad libitum with mussels of $2.50 \pm 0.35 \mathrm{~cm}$ SL. The mussels were fed with $10 \mathrm{ml}$ of suspended plankton food (DT's Live Marine Phytoplankton Premium Blend) per EU 3 times a week. During feeding, the flowthrough of the mussel EUs was stopped for $2 \mathrm{~h}$. The experimental period lasted for $10 \mathrm{wk}$.

The carbonate system was determined via the coulometric analysis of total inorganic carbon $\left(C_{\mathrm{T}}\right.$; SOMMA System autoanalyser) and $A_{\mathrm{T}}$ (potentiometric titration, VINDTA autoanalyser) at the beginning, intermediate phase and end of the experiment in each 3 representative EUs per respective treatment level and species ( 9 per measurement day). Calculations of the carbonate system speciation were performed using the

Table 1. Water carbonate system for the different treatment levels. Water $\mathrm{pCO}_{2}, \Omega_{\text {calcite }}$ and $\Omega_{\text {aragonite }}$ were calculated using measured $C_{\mathrm{T}}$ and $A_{\mathrm{T}}$ values as well as temperature and salinity values of the respective experimental units on the day of measuring with the CO2SYS macro for low salinities (Pierrot et al. 2006). Values are means $\pm \mathrm{SE}$. $A_{\mathrm{T}}$ : total alkalinity, $C_{\mathrm{T}}$ : total inorganic carbon, $\Omega$ : saturation state, SW: seawater

\begin{tabular}{|c|c|c|c|c|c|c|c|c|}
\hline \multirow{2}{*}{$\begin{array}{l}\mathrm{pCO}_{2} \text { of } \\
\text { pressurized } \\
\text { air }(\mu \mathrm{atm})\end{array}$} & & & vieasuremeI & & & \multicolumn{3}{|c|}{ Calculations } \\
\hline & $\begin{array}{c}C_{\mathrm{T}} \\
\left.(\mu \mathrm{mol} \mathrm{kgSW})^{-1}\right)\end{array}$ & $\begin{array}{c}A_{\mathrm{T}} \\
\left.(\mu \mathrm{mol} \mathrm{kgSW})^{-1}\right)\end{array}$ & $\begin{array}{c}\mathrm{pH} \\
\text { (NBS scale) }\end{array}$ & $\begin{array}{l}\text { Temp. } \\
\left({ }^{\circ} \mathrm{C}\right)\end{array}$ & Salinity & $\begin{array}{l}\mathrm{pCO}_{2} \\
\text { ( } \mu \text { atm) }\end{array}$ & $\Omega_{\text {calcite }}$ & $\Omega_{\text {aragonite }}$ \\
\hline $\begin{array}{l}\text { Ambient } \\
(>387)\end{array}$ & $1999.2 \pm 18.0$ & $2046.4 \pm 18.6$ & $8.06 \pm 0.005$ & $12.9 \pm 0.07$ & $14.8 \pm 0.13$ & $654.2 \pm 54.0$ & $1.64 \pm 0.17$ & $0.96 \pm 0.10$ \\
\hline 1120 & $2076.2 \pm 20.3$ & $2051.60 \pm 20.7$ & $7.84 \pm 0.006$ & $12.9 \pm 0.07$ & $14.8 \pm 0.13$ & $1245.7 \pm 85.8$ & $0.91 \pm 0.10$ & $0.53 \pm 0.06$ \\
\hline 4000 & $2208.8 \pm 24.0$ & $2060.54 \pm 19.5$ & $7.36 \pm 0.008$ & $12.9 \pm 0.07$ & $14.8 \pm 0.13$ & $3466.9 \pm 155.6$ & $0.34 \pm 0.03$ & $0.20 \pm 0.02$ \\
\hline
\end{tabular}




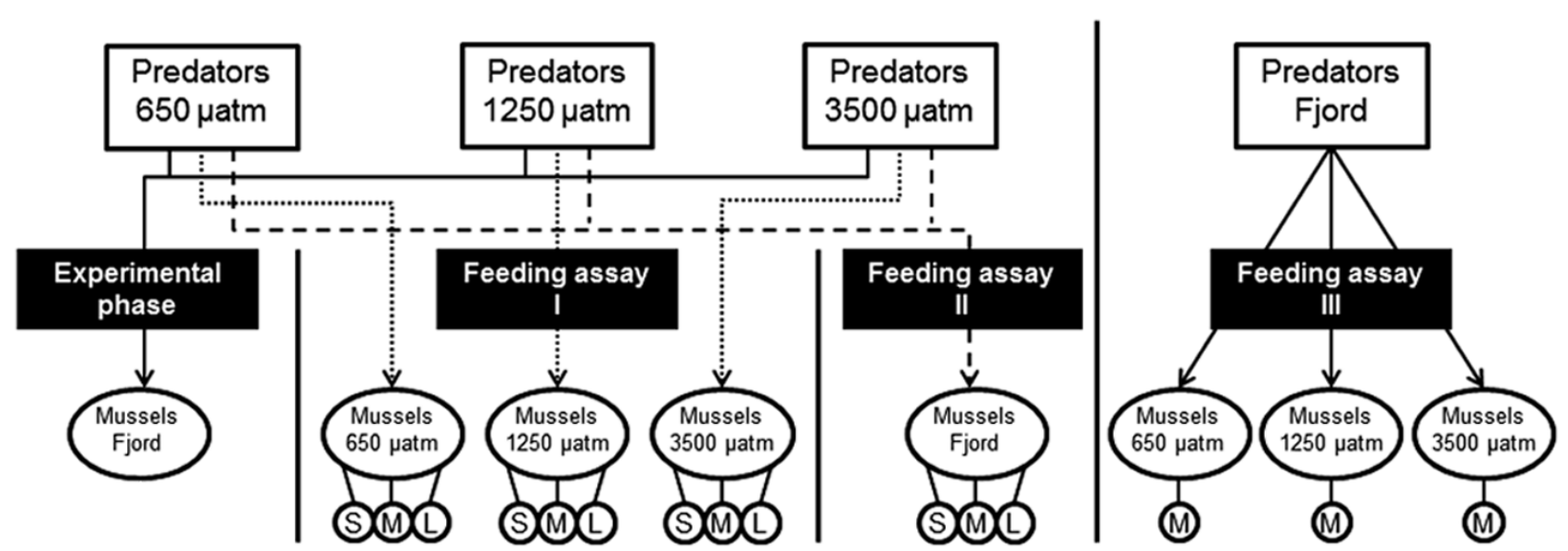

Fig. 1. Schematic overview of the experimental setup. After the experimental phase, Asterias rubens and Carcinus maenas were fed with Mytilus edulis classified into 3 sizes -S: $2.00 \pm 0.15 \mathrm{~cm}$ shell length (SL); M: $3.00 \pm 0.15 \mathrm{~cm} \mathrm{SL;} \mathrm{L:} 4.00 \pm 0.15 \mathrm{~cm}$ SL. During the experimental period, $A$. rubens and $C$. maenas were fed with mussels of $3.50 \pm 0.35 \mathrm{~cm} \mathrm{SL}$, and $2.50 \pm 0.35 \mathrm{~cm}$ SL, respectively

CO2SYS macro for low salinities (modified by Körtzinger after Pierrot et al. 2006). The dissociation constants $K_{1}$ and $K_{2}$ were chosen according to Roy et al. (1993). Additionally, the pH and salinity in the EUs was measured weekly with a hand-held $\mathrm{pH}$ meter (WTW 340i pH-analyser, WTW SenTix 81 measuring chain, using the NBS scale) and salinometer (WTW cond 315i, WTW TETRACON 325 measuring chain). The concentration of $\mathrm{NH}_{4}{ }^{+}$was determined in each of the $3 \mathrm{EUs}$ per $\mathrm{pCO}_{2}$ level at the end of the experimental period using a $\mathrm{JBL} \mathrm{NH}_{4}{ }^{+}$aquarium kit.

\section{Growth}

Biomass increase (wet wt) of the sea stars was quantified weekly, weighing each individual 3 times after gently blotting it dry with a paper towel. Mussel growth (increase in shell length) was documented as the shell length increase between the beginning and end of the experimental period. Crab growth could not be monitored because only 1 crab moulted during the experimental period.

\section{Feeding assays}

Consumption of mussels by sea stars and crabs during the experimental period was monitored weekly. After the $10 \mathrm{wk}$ of treatment at different $\mathrm{pCO}_{2}$ levels, we performed 3 different feeding assays (FA I, II and III; see Fig. 1 for an overview). In FA I, predators were starved for $1 \mathrm{~d}$ before being offered 3 mussel individuals from each of the 3 different size classes (i.e. 9 mussels) simultaneously, with consumers and prey stemming from identical experimental conditions. The number and size class of mussels consumed was monitored daily over $6 \mathrm{~d}$.

The predators were then again starved for $1 \mathrm{~d}$, after which FA II was performed, which was identical to FA I, except that the prey were not pre-treated but collected from Kiel Fjord the day before. These mussels served as external references to assess which proportion of the effects observed in Assay I were due to the predators rather than the prey. Consumption in FA II was monitored daily over $6 \mathrm{~d}$, as before.

In FA III, consumers collected from Kiel Fjord (10 sea stars and 10 crabs starved for $3 \mathrm{~d}$ ) were offered 3 prey individuals of the medium size class $(3.00 \pm$ $0.15 \mathrm{~cm}$ ) from each of the 3 treatment levels (i.e. 9 mussels). In FA III, the predators served as external references to estimate which proportion of the effects observed in FA I were attributable to the treated mussels. Monitoring of FA III took place over $6 \mathrm{~d}$ as well, but only the data obtained during Day 1 were analysed, when one of the predators had consumed all 3 mussels of one treatment level.

All of the FAs took place under the respective $\mathrm{CO}_{2}$ conditions to which the predators had been previously exposed.

\section{Acid-base status}

Following the FAs, the extracellular acid-base status of the consumer species was assessed to deter- 
mine the regulative capacities of the species. Asterias rubens was starved for $7 \mathrm{~d}$, then the tip of an arm was cut, and the coelomic fluid was collected in a cap. Crabs were starved for $3 \mathrm{~d}$, then haemolymph was drawn bubble-free with a syringe from the infrabranchial sinus without contact to air. The $\mathrm{pH}$ was measured using a microelectrode (WTW Mic-D and WTW pH 340i), and $C_{\mathrm{T}}$ was measured using a $\mathrm{CO}_{2}$ analyser (Corning 965). The $\mathrm{pCO}_{2}$ and $\mathrm{HCO}_{3}{ }^{-}$concentrations of the body fluids were calculated from the measured $\mathrm{pH}$ and $C_{\mathrm{T}}$ with the rearranged forms of the Henderson-Hasselbalch equation:

$$
\begin{gathered}
\mathrm{pCO}_{2}=C_{\mathrm{T}} \times\left(10^{\mathrm{pH}-\mathrm{pK}_{1}} \times \alpha_{\mathrm{CO}_{2}}+\alpha_{\mathrm{CO}_{2}}\right)^{-1} \\
{\left[\mathrm{HCO}_{3}^{-}\right]=10^{\mathrm{pH}-\mathrm{pK}_{1}} \times \alpha_{\mathrm{CO}_{2}} \times \mathrm{pCO}_{2}}
\end{gathered}
$$

For Carcinus maenas, the $\alpha_{\mathrm{CO}_{2}}\left(\mathrm{CO}_{2}\right.$ solubility) and $\mathrm{pK}_{1}$ (the first apparent dissociation constant) were calculated from Truchot (1986) for ambient salinity and temperature. The $\alpha_{\mathrm{CO}_{2}}$ summed to $0.000375 \mathrm{~Pa}$, and the $\mathrm{pK}_{1}$ summed to 6.065. In Asterias rubens, $\alpha_{\mathrm{CO} 2}$ was calculated from Weiss (1974). The $\mathrm{pK}_{1}$ was calculated from a linear correlation of $\mathrm{pK}$ and $\mathrm{pH}$ $\left(\mathrm{pK}=-0.1331 \mathrm{pH}+7.2481, \mathrm{r}^{2}=0.3047\right)$ determined in vitro for coelomic fluid at a given experimental salinity and temperature. For this purpose, $600 \mu \mathrm{l}$ samples of body fluid pooled from 10 animals were equilibrated with known $\mathrm{pCO}_{2}$ levels of 560, 1400, 4000 and $6000 \mu \mathrm{atm}$ for $1 \mathrm{~h}$. Afterwards, the $\mathrm{pH}$ and $C_{\mathrm{T}}$ of the samples were determined as described above. $\mathrm{pK}_{1}$ was calculated using the equation:

$$
\mathrm{pK}_{1}=\mathrm{pH}-\log \left(\frac{C_{\mathrm{T}}}{p \mathrm{CO}_{2} \times \alpha_{\mathrm{CO}_{2}}}-1\right)
$$

The $\alpha_{\mathrm{CO} 2}$ used for calculation was $0.0003888 \mathrm{~Pa}$, and the $\mathrm{pK}_{1}$ levels were $6.18 \pm 0.01$ for the $650 \mu \mathrm{atm}$ level, $6.19 \pm 0.01$ for $1250 \mu$ atm and $6.21 \pm 0.01$ for 3500 patm.

The non-bicarbonate buffer line was determined in vitro by correlation of the measured $\mathrm{pH}$ and calculated $\mathrm{HCO}_{3}{ }^{-}$concentration in equilibrated body fluid samples.

\section{Mussel properties}

The mussels not used in the FAs were frozen at $-20^{\circ} \mathrm{C}$ after the experimental period. Ten mussels of each size class and treatment level were later defrosted to determine the dry soft-tissue weight of the mussels at the respective treatment level and to correlate that weight to consumption rates. The others were used to determine adductor muscle dry wt, shell weight and maximum breaking resistance of shells. Pilot assays had shown that a freezing/ thawing treatment did not cause detectable differences in shell stability.

To determine the adductor muscle dry wt, shell weight and maximum breaking resistance of shells, 3 mussels of each size class per EU were defrosted and opened with a scalpel. The adductor muscles were dissected, dried for $24 \mathrm{~h}$ at $80^{\circ} \mathrm{C}$ until a constant weight was reached and weighed individually. The shells were dried with a paper towel, left to surfacedry at room temperature for $2 \mathrm{~h}$ and then weighed individually. The breaking resistance was determined with a TAXT2i texture analyser (25-1 measuring cell, Stable Micro Systems), using a cylinder of $2 \mathrm{~mm}$ diameter and a speed of $1.00 \mathrm{~mm} \mathrm{~s}^{-1}$, measuring the maximum force necessary for breaking the shell. For these measurements, the shells were positioned opening downwards, with the rim of the shell on a neoprene sheet to ensure homogeneous distribution of forces and the cylinder position above the highest point of the shell. Both the left and the right shell half were broken, and the higher value of the 2 was used for analysis.

\section{Statistical analyses}

The total mussel consumption of the predators during the experimental time, the total mussel consumption in FAs I and II, the growth of all 3 species and the adductor muscle weight, shell weight and maximal breaking resistance of the mussels were analysed using a 1-way ANOVA, followed by Tukey's HSD post-hoc analysis. The size range of the mussels consumed in FAs I and II was compared using a repeated-measures ANOVA (following Yun et al. 2007). Data were tested for normality using the Shapiro-Wilks $W$-test before further statistical analysis. If the data were non-normally distributed, the Box-Cox procedure was used to identify the simplest transformation to achieve normality. Percentage data were arcsine transformed. Data were tested for homogeneity of variances using Levene's test. If normality and homoscedasticity could not be achieved, we used parametric tests but lowered the $\alpha$ level to 0.01 (following Wakefield \& Murray 1998). The data of FA III were analysed using resampling and a Monte Carlo simulation with 100 permutations (compare e.g. Rohde et al. 2004). Data of coelomic fluid and haemolymph acid-base status were plotted in pH-bicarbonate (Davenport) diagrams. 


\section{RESULTS}

\section{Experimental conditions}

The mean $( \pm \mathrm{SE}) \mathrm{pCO}_{2}$ in the EUs at the 3 treatment levels was $654.2 \pm 54.0,1245.7 \pm 85.8$ and $3466.9 \pm$ 155.6 at 650,1250 and 3500 uatm (equivalent to 66, 127 and $356 \mathrm{~Pa})$, respectively, during the course of the experimental period (Table 1). Seawater $\left[\mathrm{NH}_{4}{ }^{+}\right]$ was below $0.2 \mathrm{mg} \mathrm{l}^{-1}$ in all cases.

None of the sea stars died during the experiment. One crab per treatment level died during the $10 \mathrm{wk}$ experimental period. One crab at the highest treatment level moulted $9 \mathrm{wk}$ into the experiment. Four (650 $\mu \mathrm{atm}), 3(1250 \mu \mathrm{atm})$ and 5 (3500 $\mu \mathrm{atm})$ of the 6 female crabs per treatment level spawned in Week 4 or 5 of the experimental period.

\section{Growth}

Growth of Asterias rubens over the 10 wk experimental phase was significantly lower at the
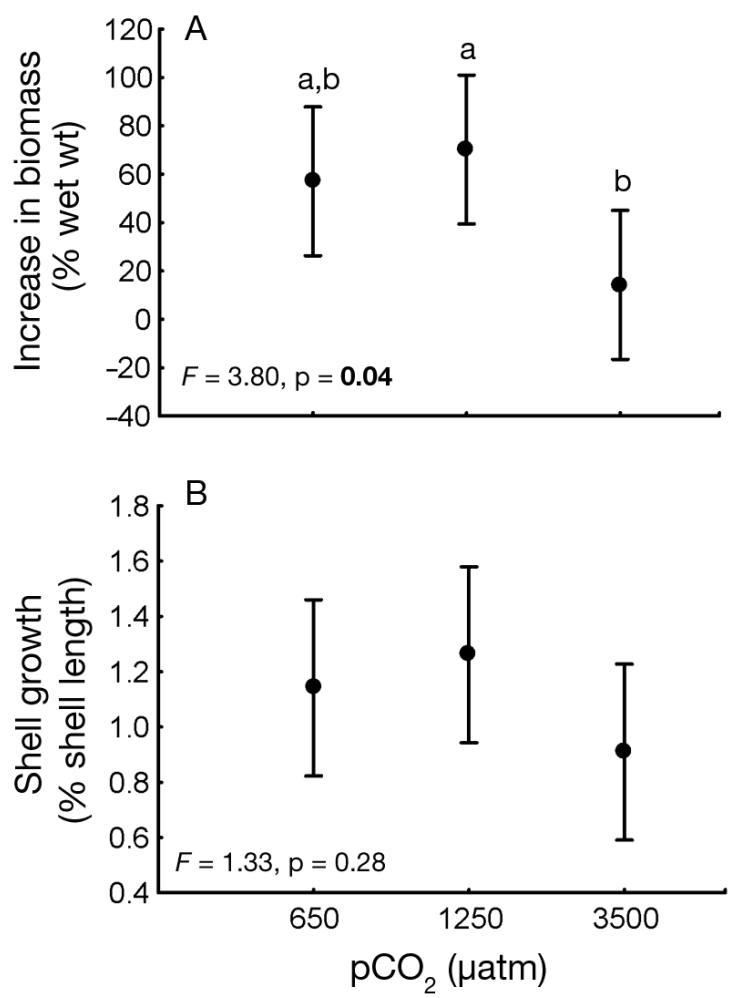

Fig. 2. (A) Asterias rubens and (B) Mytilus edulis. Mean growth during the $10 \mathrm{wk}$ experimental phase at different treatment levels. Vertical bars denote $\pm 95 \%$ CI. Results from 1-way ANOVAs followed by post-hoc testing (Tukey's HSD). Groups with different letters in (A) are significantly different at $p \leq 0.05$ (bold) high (3500 $\mu \mathrm{atm})$ than at the intermediate $\mathrm{pCO}_{2}$ (1250 $\mu \mathrm{atm})$ concentrations. Growth did not differ between the 650 and 1250 and between the 650 and 3500 uatm treatments (Fig. 2A, Table 2). Growth of Mytilus edulis (Fig. 2B, Table 2) was generally very low and not significantly affected by acidification. Crab growth was not assessed.

\section{Consumption}

Feeding behaviour of Asterias rubens during the experimental phase differed significantly between the $\mathrm{pCO}_{2}$ treatment levels, with highest consumption at the intermediate level (1250 $\mu \mathrm{atm})$ and lowest consumption at the highest (3500 $\mu \mathrm{atm})$ treatment level (Fig. 3A, Table 2). The same pattern was found in the total consumption by sea stars in FA I, in which pre-treated mussels were fed to the pre-treated sea stars (Fig. 3B, Table 2), as in FA II, in which untreated mussels were offered to the pre-treated A. rubens (Fig. 3C, Table 2). The prey-size preference exhibited by sea stars was not significantly affected by acidification in both FA I (Fig. 4A, Table 2) and FA II (Fig. 4B, Table 2). In FA III, in which pre-treated mussels were offered to untreated sea stars, significantly more mussels treated at $3500 \mu \mathrm{atm}$ were consumed within $24 \mathrm{~h}$ than mussels pre-treated with lower $\mathrm{pCO}_{2}$ levels (Fig. 3D).

In contrast to the sea stars, significant acidification effects on Carcinus maenas feeding were detected in the experimental phase only (Fig. 5A, Table 2). Here, consumption was significantly lower at 3500 patm than at the other levels. Acidification had no measurable effect on the trophic interaction between identically pre-treated mussels and crabs (FA I, Fig. 5B, Table 2), on the feeding behaviour of crabs (FA II, Fig. 5C, Table 2) or on the susceptibility of mussels to crab predation (FA III, Fig. 5D). Similar to the sea stars, the differently treated crabs did not differ in prey size preference in FA I (Fig. 6A, Table 2) or II (Fig. 6B, Table 2).

\section{Acid-base status}

The coelomic fluid $\mathrm{pH}$ ( $\mathrm{pHe}$ ) of Asterias rubens decreased with increasing seawater $\mathrm{pCO}_{2}$ along the non-bicarbonate buffer line (Fig. 7A, Table 2). We did not observe extracellular $\mathrm{HCO}_{3}$ accumulation deviating from solely passive increments, as presented in the $\mathrm{pH}$-bicarbonate (Davenport) diagram. In contrast, the haemolymph $\mathrm{pH}$ of Carcinus maenas was maintained at control $\mathrm{pH}$ levels of 7.82, indepen- 
Table 2. ANOVA with different response variables and the dependent factor $\mathrm{pCO}_{2}$ measured during the acclimatisation phase and the subsequent feeding assays (FA) and 3 different $\mathrm{pCO}_{2}$ treatments. For non-parametric data, the $\alpha$ level was adjusted to 0.01. Statistically significant results are bold. pHe: coelomic fluid $\mathrm{pH}$

\begin{tabular}{|c|c|c|c|c|c|c|}
\hline & $\alpha$ & df & MS & $F$ & $\mathrm{p}$ & Partial $\eta^{2}$ \\
\hline \multicolumn{7}{|l|}{ Asterias rubens } \\
\hline Increase in biomass & 0.05 & 2 & 8563.71 & 3.80 & 0.04 & 0.22 \\
\hline Consumption during experiment & 0.05 & 2 & 375.23 & 6.37 & 0.01 & 0.32 \\
\hline FA I, total consumption & 0.05 & 2 & 67340.00 & 4.13 & 0.03 & 0.23 \\
\hline FA II, total consumption & 0.01 & 2 & 208276.00 & 4.95 & 0.01 & 0.27 \\
\hline FA I, consumption per mussel size class & 0.01 & 4 & 1.47 & 1.98 & 0.11 & 0.13 \\
\hline FA II, consumption per mussel size class & 0.01 & 4 & 0.34 & 0.68 & 0.61 & 0.05 \\
\hline $\mathrm{pHe}$ & 0.01 & 2 & 0.20 & 40.67 & $<0.01$ & 0.75 \\
\hline $\mathrm{HCO}_{3}{ }^{-} \mathrm{e}$ & 0.01 & 2 & 0.07 & 3.08 & 0.06 & 0.19 \\
\hline \multicolumn{7}{|l|}{ Carcinus maenas } \\
\hline Increase in biomass & 0.01 & 2 & 786.81 & 0.85 & 0.44 & 0.07 \\
\hline Consumption during experiment & 0.05 & 2 & 1911.26 & 3.93 & 0.03 & 0.25 \\
\hline FA I, total consumption & 0.01 & 2 & 9505.00 & 0.31 & 0.73 & 0.03 \\
\hline FA II, total consumption & 0.01 & 2 & 57996.00 & 0.42 & 0.66 & 0.03 \\
\hline FA I, consumption per mussel size class & 0.01 & 4 & 1.04 & 2.38 & 0.06 & 0.17 \\
\hline FA II, consumption per mussel size class & 0.01 & 4 & 0.73 & 1.33 & 0.27 & 0.10 \\
\hline $\mathrm{pHe}$ & 0.01 & 2 & $<0.01$ & 0.12 & 0.88 & 0.01 \\
\hline $\mathrm{HCO}_{3}{ }^{-} \mathrm{e}$ & 0.01 & 2 & 34.00 & 5.67 & 0.01 & 0.35 \\
\hline \multicolumn{7}{|l|}{ Mytilus edulis } \\
\hline Increase in shell length & 0.01 & 2 & 0.32 & 1.33 & 0.28 & 0.09 \\
\hline Adductor muscle weight & 0.01 & 2 & $<0.01$ & 0.14 & 0.87 & 0.01 \\
\hline Shell weight & 0.01 & 2 & 4.10 & 1.12 & 0.34 & 0.08 \\
\hline Breaking resistance & 0.05 & 2 & $<0.01$ & 6.70 & $<0.01$ & 0.33 \\
\hline
\end{tabular}
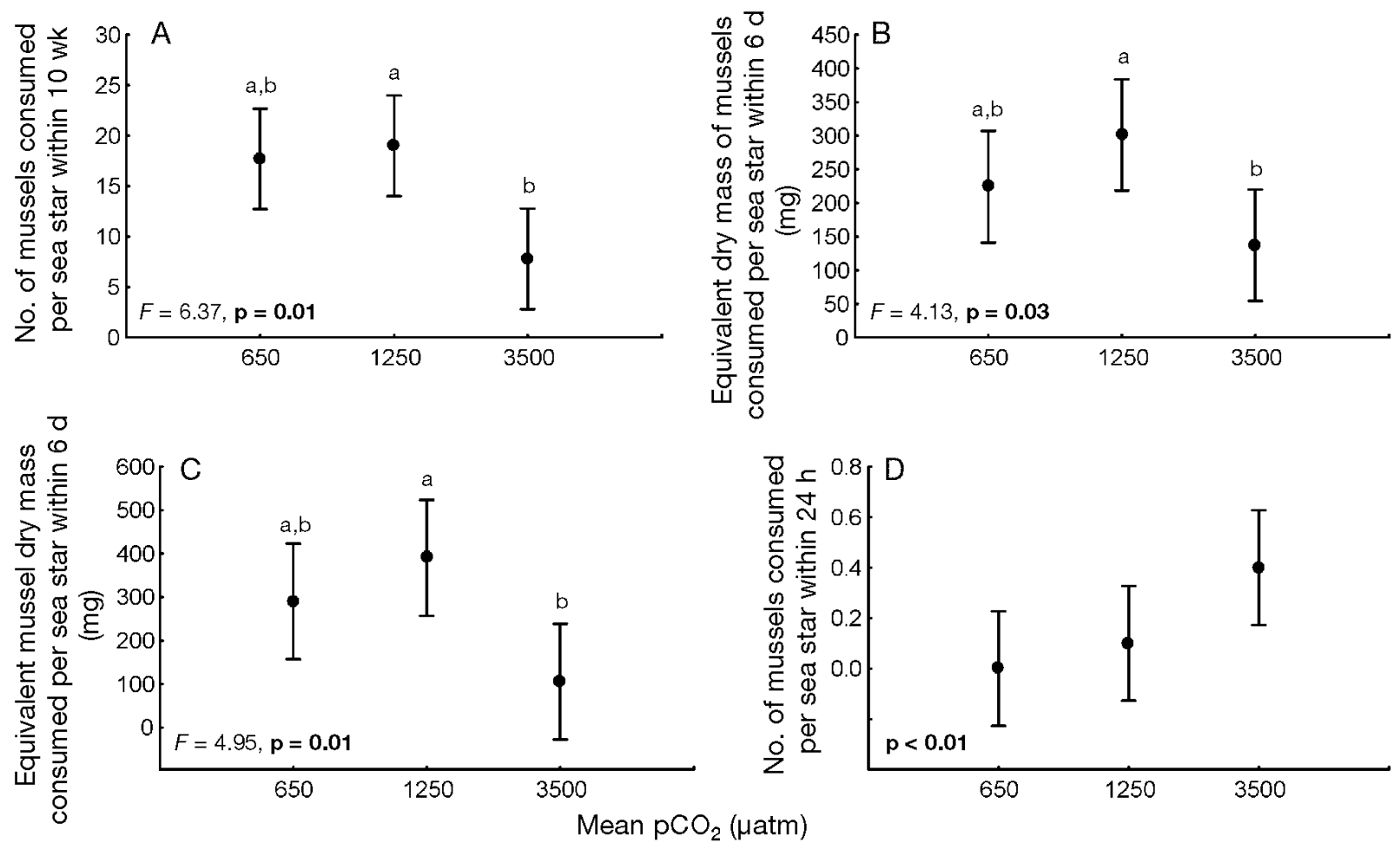

Fig. 3. Asterias rubens. Mean mussel consumption (A) during the 10 wk experimental period, (B) in feeding assay (FA) I (treated sea stars, treated mussels), (C) in FA II (treated sea stars, untreated mussels) and (D) in FA III (untreated sea stars, treated mussels) over treatment levels. Vertical bars denote $\pm 95 \%$ CI. (A-C) Results from 1-way ANOVAs followed by posthoc testing (Tukey's HSD). Groups with different letters are significantly different in $(A, B)$ at $p \leq 0.05$ or $(C) p \leq 0.01$. (D) Results from re-sampling and Monte Carlo simulation. Statistically significant $p$ values are bold 


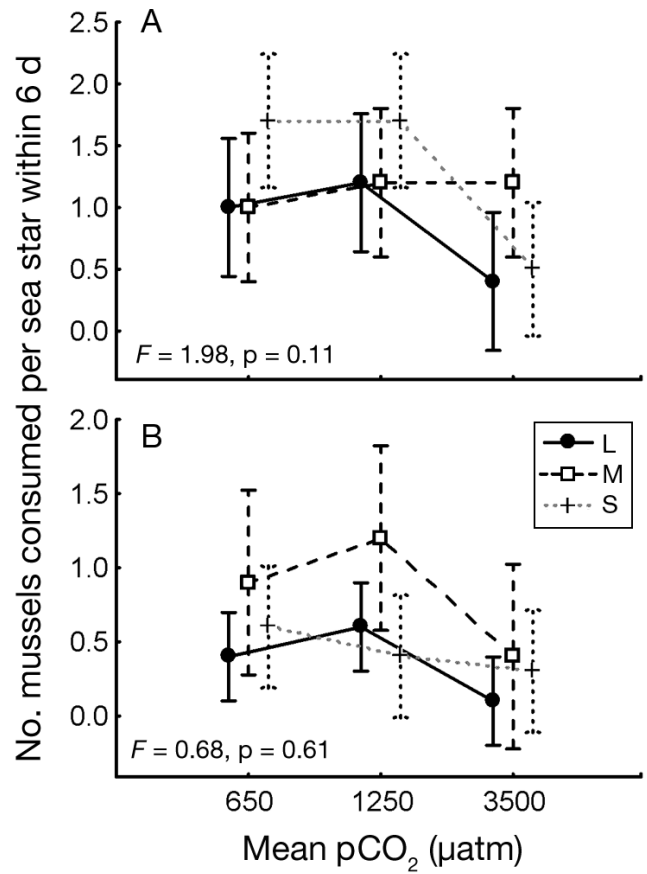

Fig. 4. Asterias rubens. Mean consumption of differently sized mussels in (A) feeding assay (FA) I (treated sea stars, treated mussels) and (B) FA II (treated sea stars, untreated mussels) over treatment levels. See Fig. 1 for mussel size classes. Vertical bars denote $\pm 95 \%$ CI. Results from repeated-measures ANOVAs dently of the $\mathrm{pCO}_{2}$ treatment level, which resulted from active elevation of $\left[\mathrm{HCO}_{3}{ }^{-}\right]$from 7.9 to 10.4 and $11.7 \mathrm{mM}$, in the 1250 and $3500 \mu \mathrm{atm} \mathrm{CO}_{2}$ treatments, respectively (Fig. 7B, Table 2 ).

\section{Mussel properties}

The dry mass of the adductor muscles (Fig. 8A, Table 2) and the shell mass (Fig. 8B, Table 2) of Mytilus edulis did not significantly differ among the treatment levels, although a trend toward a lower shell mass with increasing seawater $\mathrm{pCO}_{2}$ was observed. The mean maximum breaking resistance of mussel shells was significantly lowered by $\sim 20 \%$ at the highest level of $3500 \mu$ atm (Fig. 8C, Table 2).

\section{DISCUSSION}

Acidification effects on species interactions were mostly weak even at the high acidification levels (expected for marginal marine habitats like the Baltic Sea) where there were direct effects on the prey (e.g. increasingly fragile shell), concurrent effects on the predators (e.g. lower consumption or slower growth)
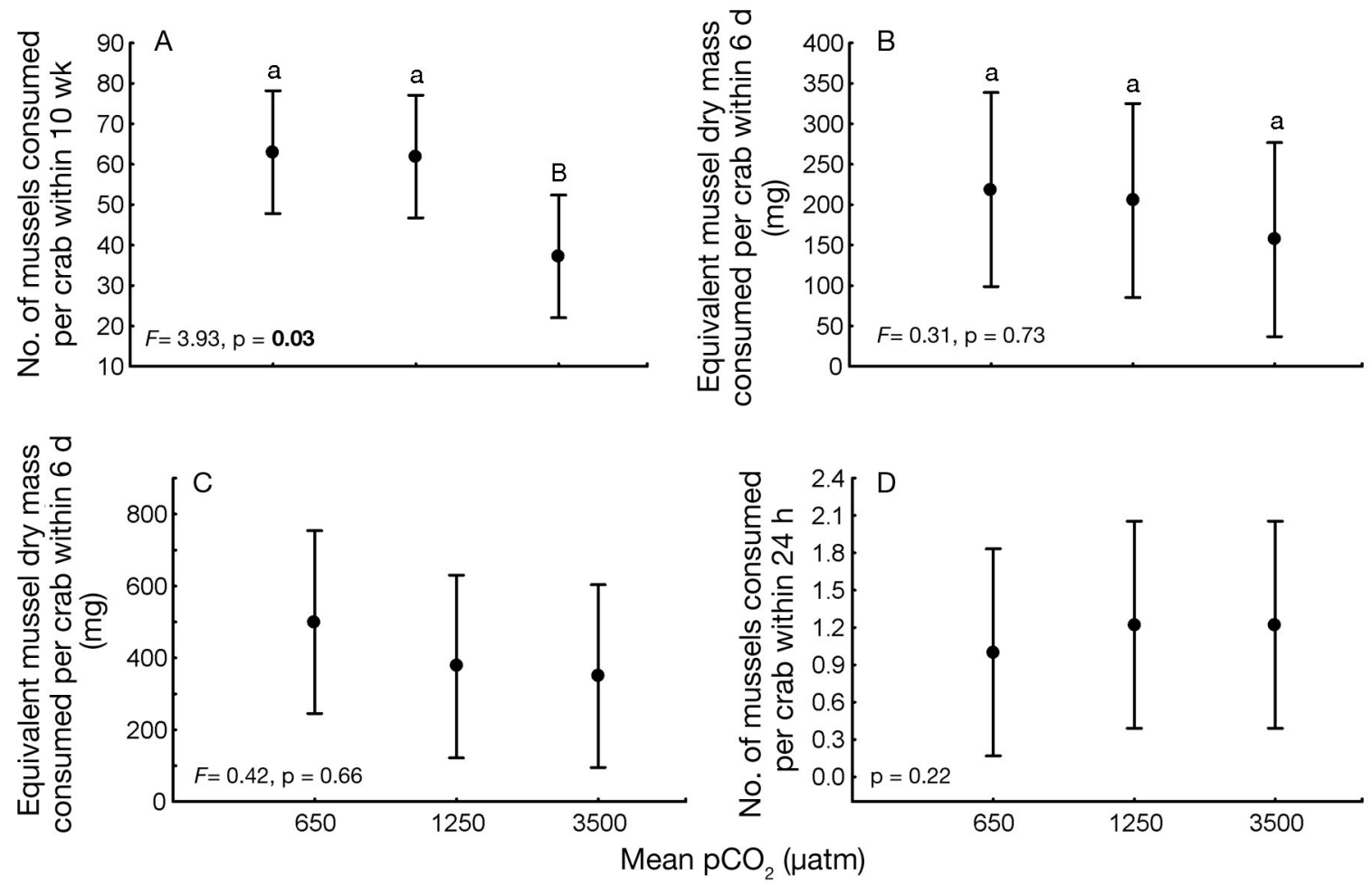

Fig. 5. Carcinus maenas. Mean mussel consumption (A) during the 10 wk experimental period, (B) in feeding assay (FA) I (treated crabs, treated mussels), (C) in FA II (treated crabs, untreated mussels) and (D) in FA III (untreated crabs, treated mussels) over treatment levels. Vertical bars denote $\pm 95 \%$ CI. Results in (A-C) from 1-way ANOVAs followed by post-hoc testing (Tukey's HSD). Groups with different letters in (A) are significantly different at $p \leq 0.05$ (bold). (D) Results from re-sampling and Monte Carlo simulation 


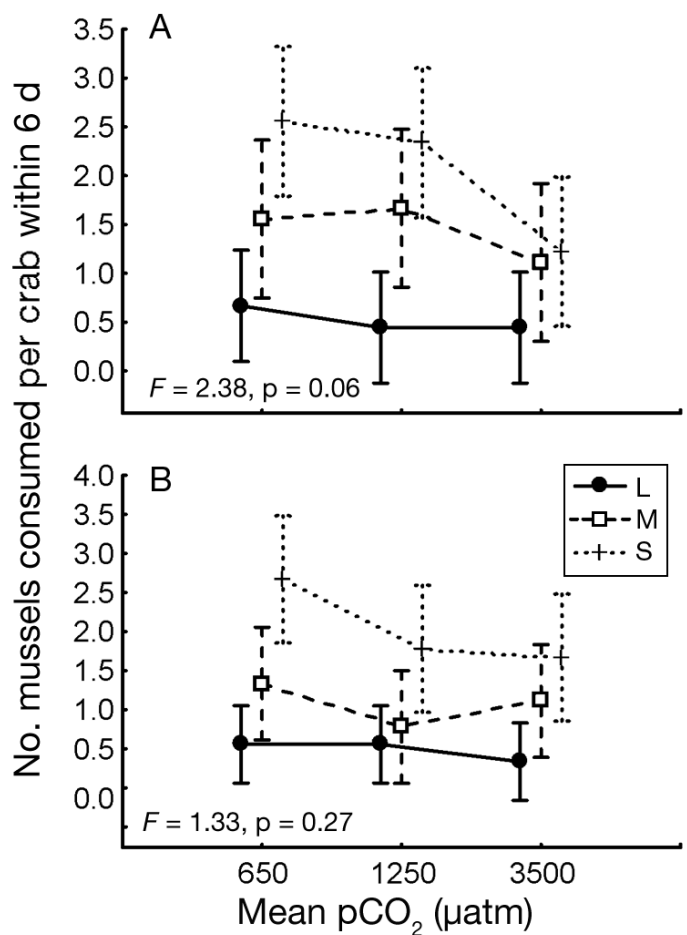

Fig. 6. Carcinus maenas. Mean consumption of differently sized mussels in (A) feeding assay I (treated crabs, treated mussels) and (B) feeding assay II (treated crabs, untreated mussels) over treatment levels. See Fig. 1 for mussel size classes. Vertical bars denote $\pm 95 \%$ CI. Results from repeatedmeasures ANOVAs

tended to neutralize any shifts in trophic interactions.

Even though the seawater was undersaturated in aragonite in all treatment levels and in calcite in the 2 higher $\mathrm{pCO}_{2}$ levels, both predator organisms were able to survive under acidified conditions. These observations are in line with recent acidification studies on crabs and echinoderms (Dupont \& Thorndyke 2008, Wood et al. 2008, Gooding et al. 2009, Dupont et al. 2010a, 2010b, Whiteley 2011). Furthermore, no significant responses of feeding rate and/or growth were observed under moderate (1250 $\mu \mathrm{atm})$ seawater acidification scenarios.

\section{Asterias rubens}

Feeding and growth of Asterias rubens were only negatively affected at the highest $\mathrm{CO}_{2}$ level (3500 uatm), whereas intermediate acidification (1250 uatm) even seemed to slightly enhance growth and consumption. A natural pre-adaptation to acidified conditions could explain this pattern. Because the benthic habitat of sea stars, especially in eutrophic coastal zones, is often an area of high decomposition, the $\mathrm{CO}_{2}$ levels in these regions are often substantially higher than in the pelagic environment (Feely et al. 2008, Melzner et al. 2009, Thomsen et al. 2010). The mean $\mathrm{pH}$ at $10 \mathrm{~m}$ depth in Kiel Fjord was 7.7 ( $\pm 0.2 \mathrm{SD}$, corresponding to a $\mathrm{pCO}_{2}$ of $\left.\sim 1400 \mu \mathrm{atm}\right)$ between May and October 2009 (Wahl et al. 2010) and was probably periodically lower at the sediment-water interface (see also Thomsen et al. 2010). Consistent with our findings, Gooding et al. (2009) report that the sea star Pisaster ochraceus grew significantly better and tended to consume more mussels under intermediate acidification levels (780 $\mu \mathrm{atm})$, which, however, were closer to our natural 'low' than to our intermediate level. Also, larvae and juveniles of the sea star Crossaster papposus showed faster growth and development under a $\mathrm{pH}$ of 7.7 than under a pH of 8.1 (Dupont et al. 2010a). Our findings indicate that moderate acidification (up to at least 1250 patm) does not stress A. rubens enough to significantly reduce feeding rates, although abiotic stress in general can lead to reduced feeding rates in asteroids. For example, strong osmotic stress in the sea star Luidia clathrata (abrupt salinity reduction from 28 to 17) has been shown to lead to depressed feeding rates over 30 d (Forcucci \& Lawrence 1986).

Sea star tolerance to acidification was reduced at very high levels of acidification, as reflected in reduced growth and consumption rates. The underlying cause is not clear. However, recent studies have demonstrated that acidification can lead to energy budget re-allocations that result in a reduction of the scope for growth in larval and adult echinoderms (Stumpp et al. 2011). Excess energy might be required for the maintenance of intracellular $\mathrm{pH}$ when the extracellular $\mathrm{pH}$ is decreased (e.g. Michaelidis et al. 2005, Thomsen \& Melzner 2010), thus limiting the amount of energy that can be invested into digestion, assimilation and growth. In addition, the low pHe could impact the energy available for calcification. However, energetic trade-offs are mostly relevant under energy-limited conditions, which we attempted to avoid in our experimental design. It is also possible that decreased feeding rates were connected to a reduced functionality of digestive enzymes, if stomach $\mathrm{pH}$ was affected by seawater acidification or if more energy had to be invested into stomach $\mathrm{pH}$ regulation (which we did not assess). The stomach $\mathrm{pH}$ of adult asteroids has been shown to be between 7.3 and 7.5, and an optimum of enzymatic activity was found at a similar pH (Irving 1926). The change in extracellular and environmental $\mathrm{pH}$ in our study might have caused a decrease in enzyme activity. 


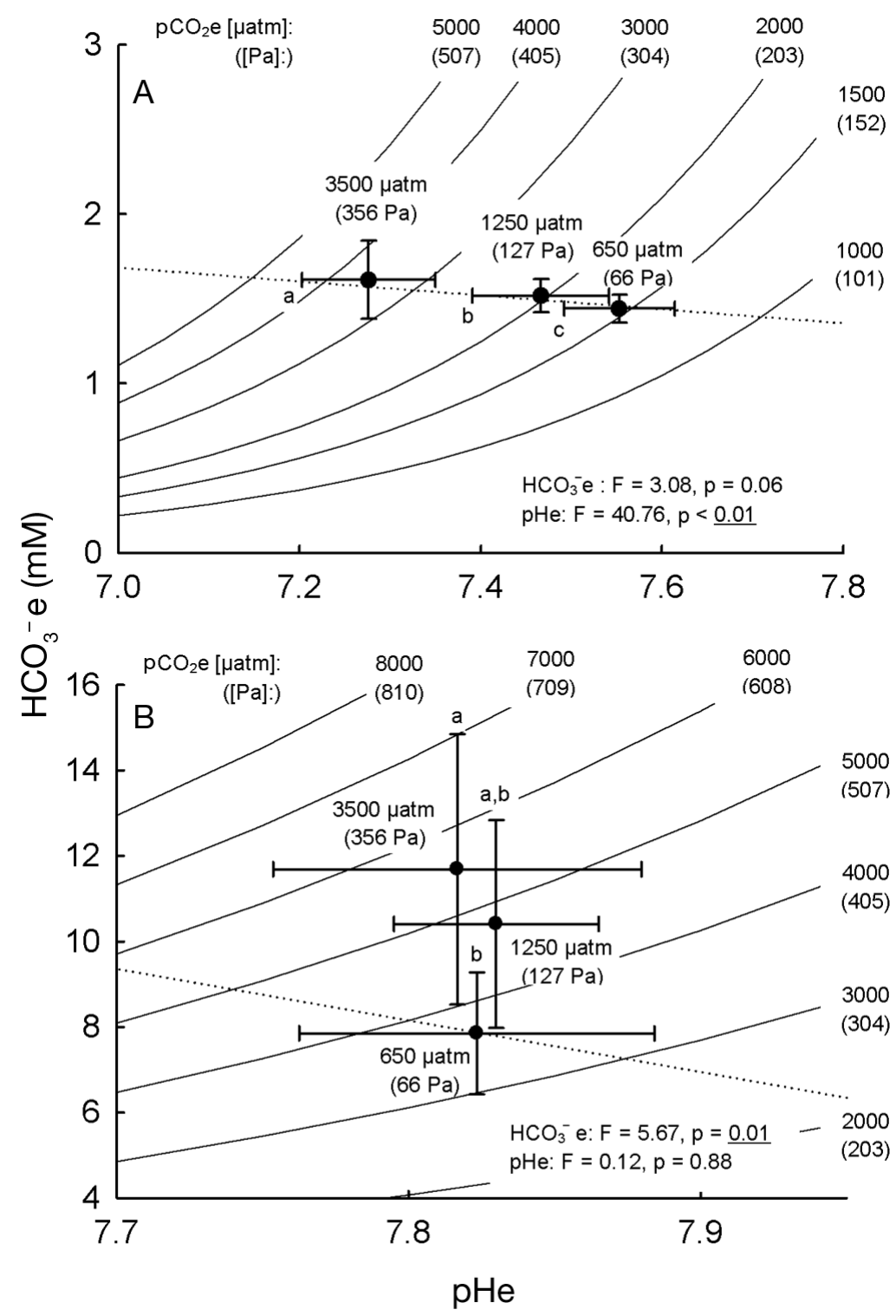

Fig. 7. pH-bicarbonate (Davenport) diagrams of (A) coelomic fluid of Asterias rubens and (B) haemolymph of Carcinus maenas at the different treatment levels. Vertical and horizontal bars are standard deviations. Isopleths display $\mathrm{pCO}_{2}$. Dotted line indicates non-bicarbonate buffer line. Statistical results from 1-way ANOVAs. Groups with identical letters do not differ in (a) extracellular $\mathrm{pH}(\mathrm{pHe})$ and (b) extracellular $\mathrm{HCO}_{3}{ }^{-}\left(\mathrm{HCO}_{3}{ }^{-} \mathrm{e}\right)$ at $\mathrm{p} \leq 0.01$

\section{Carcinus maenas}

Similar to Asterias rubens, the shore crab Carcinus maenas was not influenced in feeding at moderate (1250 $\mu \mathrm{atm})$ seawater acidification. At the highest $\mathrm{pCO}_{2}$, a significant reduction in feeding was observed during the comparatively long period of the experiment but not in the subsequent feeding assays. Because only one of the crabs moulted during the entire study period, we cannot be certain whether or not the growth of crabs is affected by acidification. However, a relative insensitivity of decapod crustaceans towards short-term acidification stress has been demonstrated (e.g. Spicer et al. 2007) and has been explained by their high regulatory capacity. In contrast, Kurihara et al. (2008) found significantly lower moulting frequencies and growth of the shrimp Palaemon pacificus when exposed to $\mathrm{CO}_{2}$ levels of 1900 patm over a longer time period of $30 \mathrm{wk}$. Our results clearly show that the crabs, in contrast to sea stars, can compensate $\mathrm{pHe}$ when facing substantial $\mathrm{pH}$ shifts in their environment. A compensation of respiratory acidosis caused by hypercapnia has been demonstrated before, and its mechanisms were explained by accumulation of $\mathrm{HCO}_{3}{ }^{-}$in the haemolymph (Truchot 1979). While shortterm $\mathrm{pHe}$ regulation in crabs is probably necessary for efficient haemocyanin-mediated blood oxygen transport (e.g. Lallier \& Truchot 1989), it cannot be excluded that, in the long term, the excess amount of energy invested in pHe regulation negatively impacts energy allocation to other processes, such as reproduction, growth or even feeding processes (e.g. digestion or prey handling). Again, this would mainly apply for energy-limited conditions.

Only one of the crabs moulted during the experimental period in our study. This long intermoult period is not unusual for the crab size used in our experiments and the prevailing water temperature (Adelung 1971, Klein Breteler 1975, Hartnoll 2001). Monitoring growth rates and moulting intervals over a longer time period (6 to $12 \mathrm{mo}$ ) may therefore be necessary to test whether acidification impacts energy allocation into somatic growth in Carcinus maenas and whether calcification effects increase with increasing time exposure to high $\mathrm{pCO}_{2}$ seawater and the concomitant increases in haemolymph $\left[\mathrm{HCO}_{3}{ }^{-}\right]$.

In the previously mentioned study by Kurihara et al. (2008), no differences in feeding rates were found between shrimp treated at ambient conditions, 1000 and 1900 patm. However, previous studies have shown the handling time of mussels by Carcinus maenas to be extended and thus the consumption rates reduced when crabs were kept under other stressful conditions, such as hypoxia (Brante \& Hughes 2001). Melzner et al. (2009) proposed that organisms with high and highly fluctu- 

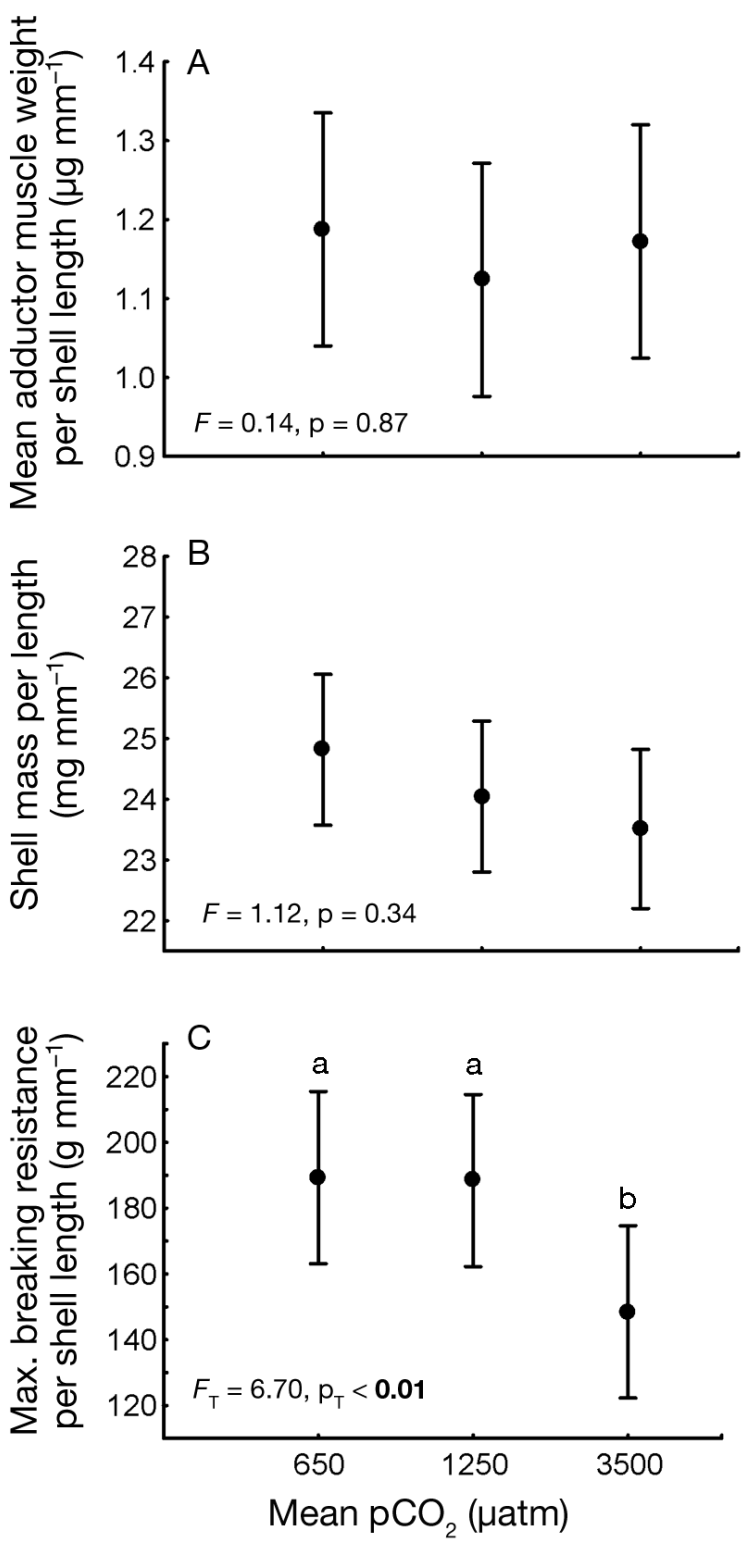

Fig. 8. Mytilus edulis. (A) Mean adductor muscle dry weight per shell length, (B) mean shell weight per shell length and (C) mean maximal breaking resistance of the mussel shell after the experimental period. Vertical bars denote $\pm 95 \%$ CI. Results from 1-way ANOVAs followed by post-hoc testing (Tukey's HSD). Groups with different letters are significantly different in $(C)$ at $p \leq 0.05$ (bold). Subscript $T$ : value derived from transformed data

ating metabolic rates (thus, high fluctuations in extracellular fluid $\mathrm{pCO}_{2}$ ) should, on average, cope better with increases in environmental $\mathrm{pCO}_{2}$. This concept, however, is based on the assumption that uncompensated pHe leads to metabolic depression (Pörtner et al. 2004), which does not seem to hold true in all cases. In our study, sea stars in the inter- mediate treatment suffered from respiratory acidosis, but mussel flesh consumption tended to increase. Also, a few other studies on organisms of different phyla show that metabolic rates may remain constant or even increase under conditions of acidification in organisms that do not compensate pHe (Beniash et al. 2010, Comeau et al. 2010, Lannig et al. 2010, Thomsen \& Melzner 2010). The crabs in our experiments, although completely compensating pHe, demonstrated decreased food consumption during the experimental period at $3500 \mu \mathrm{atm}$, indicating that impacts of elevated seawater $\mathrm{pCO}_{2}$ are not exclusively related to extracellular acid-base status.

\section{Influence of the prey organism}

The fact that the consumption of mussels pretreated under the highest acidification levels were targeted by untreated sea stars suggests that the adductor muscle strength of the mussels might have been weakened. Wood et al. (2008) proposed that the change in the $\mathrm{Ca}^{2+}$ to arm mass ratio in regenerated arms of brittle stars indicates higher levels of calcification but less muscle tissue biomass when the organisms are grown under acidified conditions ( $\mathrm{pH}$ of $7.7,7.3$ and 6.8). In the present study, no differences in posterior adductor muscle mass were detected among the treatment levels. Possibly, rather than degrading muscle, acidification affected the catch phase of the smooth muscle by an as yet unknown cause. Surprisingly, despite a significant decrease in the breaking resistance of the shell, mussels did not become more susceptible to crab predation under high acidification levels. Because the consumption efficacy of the crabs was not impacted by acidification, as verified by offering reference prey in FA II, the decrease in shell stability was either too small to enhance vulnerability or was compensated for by other as yet unknown factors. It has previously been suggested that in addition to shell stability (Kossak 2006), the handleability of a mussel is a crucial factor limiting crab consumption (Enderlein et al. 2003).

Although it is possible that our results concerning mussel performance are slightly biased by generally low growth rates, which might have been caused by food quality and quantity (Melzner et al. 2011), our results suggest that the influence on the size and amount of mussels consumed is more dependent on the recent history of the predators than their prey. 


\section{Conclusions}

All 3 species show a shift in certain traits when exposed to high levels of acidification. Mussel shells become more brittle, sea stars (which cannot compensate pHe) grow slower, and both sea stars and crabs (the latter capable of pHe compensation) feed less under strong acidification. Interestingly, the enhanced vulnerability of mussels seems to be neutralised by the decreased consumption of the predators under high acidification. These results illustrate that different stress effects on interacting species may not only enhance but also buffer community level effects. The overall weak effects of substantial acidification on the species studied here confirm the expectation of enhanced tolerance of hypercapnic hypoxia in the low-salinity and periodically hypoxic Baltic (Thomsen et al. (2010).

Acknowledgements. This study was financed by the German National Academic Foundation, the cluster of excellence 'the future ocean' (Deutsche Forschungsgesellschaft; Neglected Bottleneck: D1067/34.1) and the BioAcid project (Federal Ministry of Education and Research; D10/4.1.2; FKZ 03F0608A). Further, we thank A. Körtzinger for advice on the manipulation of the carbonate system, S. Fessler for help with the water chemistry analysis, A. L. Semiao Lopes for help with the setup of the experiment, A. Regulin and M. Paar for maintenance, S. Fehsenfeld, M. Gutowska and U. Panknin for assistance with the physiological work and P. Schubert as well as the crew of the RV 'Polarfuchs' for help with the collection of sea stars and crabs. We thank the editor and 3 anonymous reviewers for substantially improving the manuscript.

\section{LITERATURE CITED}

Adelung D (1971) Untersuchungen zur Häutungsphysiologie der dekapoden Krebse am Beispiel der Strandkrabbe Carcinus maenas. Helgol Wiss Meeresunters 22:66-119

> Andersson AJ, Mackenzie FT, Bates NR (2008) Life on the margin: implications of ocean acidification on Mg-calcite, high latitude and cold-water marine calcifiers. Mar Ecol Prog Ser 373:265-273

> Beldowski J, Löffler A, Schneider B, Joensuu L (2010) Distribution and biogeochemical control of total $\mathrm{CO}_{2}$ and total alkalinity in the Baltic Sea. J Mar Syst 81:252-259

Beniash E, Ivanina A, Lieb NS, Kurochkin I, Sokolova IM (2010) Elevated level of carbon dioxide affects metabolism and shell formation in oysters Crassostrea virginica. Mar Ecol Prog Ser 419:95-108

Bibby R, Cleall-Harding P, Rundle S, Widdicombe S, Spicer $\mathrm{J}$ (2007) Ocean acidification disrupts induced defences in the intertidal gastropod Littorina littorea. Biol Lett 3: 699-701

Brante A, Hughes RN (2001) Effect of hypoxia on the preyhandling behaviour of Carcinus maenas feeding on
Mytilus edulis. Mar Ecol Prog Ser 209:301-305

> Caldeira K, Wickett ME (2005) Ocean model predictions of chemistry changes from carbon dioxide emissions to the atmosphere and ocean. J Geophys Res C 110:C09S04 doi: 10.1029/2004JC002671

Checkley DM, Dickson AG, Takahashi M, Radich JA, Eisenkolb N, Asch R (2009) Elevated $\mathrm{CO}_{2}$ enhances otolith growth in young fish. Science 324:1683

Comeau S, Jeffree R, Teyssie JL, Gattuso JP (2010) Response of the Arctic pteropod Limacina helicina to projected future environmental conditions. PLoS ONE 5:e11362

Dupont S, Thorndyke M (2008) Ocean acidification and its impact on the early life-history stages of marine animals. In: Briand F (ed) Impacts of acidification on biological, chemical and physical systems in the Mediterranean and Black Seas, Book 36. CIESM Monographs, Monaco

Dupont S, Havenhand J, Thorndyke W, Peck L, Thorndyke $\mathrm{M}$ (2008) Near-future level of $\mathrm{CO}_{2}$-driven ocean acidification radically affects larval survival and development in the brittlestar Ophiothrix fragilis. Mar Ecol Prog Ser 373:285-294

$>$ Dupont S, Lundve B, Thorndyke M (2010a) Near future ocean acidification increases growth rate of the lecithotrophic larvae and juveniles of the sea star Crossaster papposus. J Exp Zool B 314:382-389

Dupont S, Ortega-Martinez O, Thorndyke M (2010b) Impact of near-future ocean acidification on echinoderms. Ecotoxicology 19:449-462

> Ellis RP, Bersey J, Rundle SD, Hall-Spencer JM, Spicer JI (2009) Subtle but significant effects of $\mathrm{CO}_{2}$ acidified seawater on embryos of the intertidal snail, Littorina obtusata. Aquat Biol 5:41-48

Enderlein P, Wahl M (2004) Dominance of blue mussels versus consumer-mediated enhancement of benthic diversity. J Sea Res 51:145-155

Enderlein P, Moorthi S, Rohrscheidt H, Wahl M (2003) Optimal foraging versus shared doom effects: interactive influence of mussel size and epibiosis on predator preference. J Exp Mar Biol Ecol 292:231-242

> Fabry VJ (2008) Ocean science: Marine calcifiers in a high$\mathrm{CO}_{2}$ ocean. Science 320:1020-1022

> Feely RA, Sabine CL, Lee K, Berelson W, Kleypas J, Fabry VJ, Millero FJ (2004) Impact of anthropogenic $\mathrm{CO}_{2}$ on the $\mathrm{CaCO}_{3}$ system in the oceans. Science 305:362-366

Feely RA, Sabine CL, Hernandez-Ayon JM, Ianson D, Hales B (2008) Evidence for upwelling of corrosive 'acidified' water onto the continental shelf. Science 320:1490-1492

> Forcucci D, Lawrence JM (1986) Effect of low salinity on the activity, feeding, growth and absorption efficiency of Luidia Clathrata (Echinodermata, Asteroidea). Mar Biol 92:315-321

Gazeau F, Quiblier C, Jansen JM, Gattuso JP, Middelburg JJ, Heip CHR (2007) Impact of elevated $\mathrm{CO}_{2}$ on shellfish calcification. Geophys Res Lett 34:L07603 doi: 10.1029/ 2006CL028554

> Gooding RA, Harley CDG, Tang E (2009) Elevated water temperature and carbon dioxide concentration increase the growth of a keystone echinoderm. Proc Natl Acad Sci USA 106:9316-9321

Gutowska MA, Pörtner HO, Melzner F (2008) Growth and calcification in the cephalopod Sepia officinalis under elevated seawater $\mathrm{pCO}_{2}$. Mar Ecol Prog Ser 373:303-309

Gutowska M, Melzner F, Pörtner H, Meier S (2010) Cuttlebone calcification increases during exposure to elevated 
seawater $\mathrm{pCO}_{2}$ in the cephalopod Sepia officinalis. Mar Biol 157:1653-1663

Hall-Spencer JM, Rodolfo-Metalpa R, Martin S, Ransome E and others (2008) Volcanic carbon dioxide vents show ecosystem effects of ocean acidification. Nature 454: 96-99

Hartnoll RG (2001) Growth in Crustacea-twenty years on. Hydrobiologia 449:111-122

Hendriks IE, Duarte CM, Alvarez M (2010) Vulnerability of marine biodiversity to ocean acidification: a metaanalysis. Estuar Coast Shelf Sci 86:157-164

IPCC (2007) Climate change 2007: the physical science basis. Contribution of Working Group I to the fourth assessment report of the Intergovernmental Panel on Climate Change. Cambridge University Press, Cambridge and New York, NY

> Irving L (1926) Regulation of the hydrogen ion concentration and its relation to metabolism and respiration in the starfish. J Gen Physiol 10:345-358

Kautsky H, van der Maarel E (1990) Multivariate approaches to the variation in phytobenthic communities and environmental vectors in the Baltic Sea. Mar Ecol Prog Ser 60:169-184

Klein Breteler WMC (1975) Laboratory experiments on the influence of environmental factors on the frequency of moulting and the increase in size and moulting of juvenile shore crabs, Carcinus maenas. Neth J Sea Res 9: 100-120

Kossak U (2006) How climate change translates into ecological change: impacts of warming and desalination on prey properties and predator-prey interactions in the Baltic Sea. PhD dissertation, Christian-Albrechts-Universität zu Kiel

Kroeker KJ, Kordas RL, Crim RN, Singh GG (2010) Metaanalysis reveals negative yet variable effects of ocean acidification on marine organisms. Ecol Lett 13: 1419-1434

- Kurihara H, Shirayama Y (2004) Effects of increased atmospheric $\mathrm{CO}_{2}$ on sea urchin early development. Mar Ecol Prog Ser 274:161-169

> Kurihara H, Shimode S, Shirayama Y (2004) Effects of raised $\mathrm{CO}_{2}$ concentration on the egg production rate and early development of two marine copepods (Acartia steueri and Acartia erythraea). Mar Pollut Bull 49:721-727

> Kurihara H, Kato S, Ishimatsu A (2007) Effects of increased seawater $\mathrm{pCO}_{2}$ on early development of the oyster Crassostrea gigas. Aquat Biol 1:91-98

Kurihara H, Matsui M, Furukawa H, Hayashi M, Ishimatsu A (2008) Long-term effects of predicted future seawater $\mathrm{CO}_{2}$ conditions on the survival and growth of the marine shrimp Palaemon pacificus. J Exp Mar Biol Ecol 367: 41-46

> Lallier F, Truchot JP (1989) Hemolymph oxygen transport during environmental hypoxia in the shore crab, Carcinus maenas. Respir Physiol 77:323-336

> Lannig G, Eilers S, Pörtner HO, Sokolova IM, Bock C (2010) Impact of ocean acidification on energy metabolism of oyster, Crassostrea gigas: changes in metabolic pathways and thermal response. Mar Drugs 8:2318-2339

> Laudien J, Wahl M (2004) Associational resistance of fouled blue mussels (Mytilus edulis) against starfish (Asterias rubens) predation: relative importance of structural and chemical properties of the epibionts. Helgol Mar Res 58: 162-167
Melzner F, Gutowska MA, Langenbuch M, Dupont S and others (2009) Physiological basis for high $\mathrm{CO}_{2}$ tolerance in marine ectothermic animals: pre-adaptation through lifestyle and ontogeny? Biogeosciences 6:2313-2331

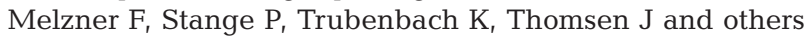
(2011) Food supply and seawater $\mathrm{pCO}_{2}$ impact calcification and internal shell dissolution in the blue mussel Mytilus edulis. PLoS ONE 6:e24223

Metzger R, Sartoris FJ, Langenbuch M, Pörtner HO (2007) Influence of elevated $\mathrm{CO}_{2}$ concentrations on thermal tolerance of the edible crab Cancer pagurus. J Therm Biol 32:144-151

Michaelidis B, Ouzounis C, Paleras A, Pörtner HO (2005) Effects of long-term moderate hypercapnia on acid-base balance and growth rate in marine mussels Mytilus galloprovincialis. Mar Ecol Prog Ser 293:109-118

Miles H, Widdicombe S, Spicer JI, Hall-Spencer J (2007) Effects of anthropogenic seawater acidification on acidbase balance in the sea urchin Psammechinus miliaris. Mar Pollut Bull 54:89-96

Pierrot D, Lewis E, Wallace DWR (2006) MS Excel program developed for $\mathrm{CO}_{2}$ system calculations. Macro for low salinities. Carbon Dioxide Information Analysis Center, Oak Ridge National Laboratory, US Department of Energy, Oak Ridge, TN

Pörtner HO, Langenbuch M, Reipschläger A (2004) Biological impact of elevated ocean $\mathrm{CO}_{2}$ concentrations: lessons from animal physiology and earth history. J Oceanogr 60: $705-718$

Reusch TBH, Chapman ARO (1997) Persistence and space occupancy by subtidal blue mussel patches. Ecol Monogr 67:65-87

> Rohde S, Molis M, Wahl M (2004) Regulation of antiherbivore defence by Fucus vesiculosus in response to various cues. J Ecol 92:1011-1018

Roy RN, Roy LN, Vogel KM, Portermoore C and others (1993) The dissociation constants of carbonic acid in seawater at salinities 5 to 45 and temperatures 0 to $45^{\circ} \mathrm{C}$. Mar Chem 44:249-267

> Sommer U, Meusel B, Stielau C (1999) An experimental analysis of the importance of body-size in the seastarmussel predator-prey relationship. Acta Oecol 20:81-86

Spicer JI, Raffo A, Widdicombe S (2007) Influence of $\mathrm{CO}_{2}{ }^{-}$ related seawater acidification on extracellular acid-base balance in the velvet swimming crab Necora puber. Mar Biol 151:1117-1125

Stumpp M, Wren J, Melzner F, Thorndyke MC, Dupont ST (2011) $\mathrm{CO}_{2}$ induced seawater acidification impacts sea urchin larval development I: elevated metabolic rates decrease scope for growth and induce developmental delay. Comp Biochem Physiol Part A Mol Integr Physiol 160:331-340

Thomsen J, Melzner F (2010) Moderate seawater acidification does not elicit long-term metabolic depression in the blue mussel Mytilus edulis. Mar Biol 157:2667-2676

> Thomsen J, Gutowska M, Saphörster J, Heinemann A and others (2010) Calcifying invertebrates succeed in a naturally $\mathrm{CO}_{2}$-rich coastal habitat but are threatened by high levels of future acidification. Biogeosciences 7 : 3879-3891

Truchot JP (1979) Mechanisms of the compensation of blood respiratory acid-base disturbances in the shore crab, Carinus maenas (L). J Exp Zool 210:407-416

> Truchot JP (1986) Changes in the hemolymph acid-base 
state of the shore crab, Carcinus maenas, exposed to simulated tidepool conditions. Biol Bull 170:506-518

Tunnicliffe V, Davies KTA, Butterfield DA, Embley RW, Rose JM, Chadwick WW (2009) Survival of mussels in extremely acidic waters on a submarine volcano. Nat Geosci 2:344-348

Twarog BM (1967) Factors influencing contraction and catch in Mytilus smooth muscle. J Physiol 192:847-856

Wahl M (2008) Ecological lever and interface ecology: epibiosis modulates the interactions between host and environment. Biofouling 24:427-438

Wahl M, Shahnaz L, Dobretsov S, Saha M and others (2010) Ecology of antifouling resistance in the bladder wrack Fucus vesiculosus: patterns of microfouling and antimicrobial protection. Mar Ecol Prog Ser 411:33-48

Editorial responsibility: Gretchen Hofmann, Santa Barbara, CA, USA
Wakefield RL, Murray SN (1998) Factors influencing food choice by the seaweed-eating marine snail Norrisia norrisi (Trochidae). Mar Biol 130:631-642

Weiss RF (1974) Carbon dioxide in water and seawater: the solubility of a non-ideal gas. Mar Chem 2:203-215

Whiteley NM (2011) Physiological and ecological responses of crustaceans to ocean acidification. Mar Ecol Prog Ser 430:257-271

Wood HL, Spicer J, Widdicombe S (2008) Ocean acidification may increase calcification rates, but at a cost. Proc $\mathrm{R}$ Soc Lond B 275:1767-1773

Yun HY, Cruz J, Treitschke M, Wahl M, Molis M (2007) Testing for the induction of anti-herbivory defences in four Portuguese macroalgae by direct and water-borne cues of grazing amphipods. Helgol Mar Res 61:203-209

Submitted: December 20, 2010; Accepted: February 29, 2012 Proofs received from author(s): June 29, 2012 